\title{
Drought Analysis and Resilient Strategies: The Case of Lake Van Basin
}

\author{
Buse ÖZER ${ }^{1 *}$ Özge YALÇINER ERCOŞKUN ${ }^{2}$
}

\begin{abstract}
Drought progresses more slowly than other natural disasters and is noticed late. It starts with decreasing precipitation and affects all human activities. Considering the effects of increasing climate change and past droughts, it is certain that drought will be inevitable in the future. Until now, many countries have experienced drought, including Turkey. Several publications have appeared in recent years documenting drought in different regions and basins in our country; however, there is no study presenting drought analysis and subsequent strategies in Lake Van Basin, which has large agricultural areas. The aim of this study is to reveal the meteorological droughts experienced in the past years in Lake Van Basin and to determine the resilience strategies for these droughts, considering the characteristics of the basin. To that end, Standardized Precipitation Index (SPI) was employed in this study to detect past meteorological droughts and calculate drought values. Spatial analyses were mapped using ArcGIS software with Inverse Distance Weighted (IDW) interpolation method. Then, the maps were evaluated for each year between 2010 and 2019.
\end{abstract}

Online interview is used with relevant expert who worked as project expert in the Lake Van Basin Drought Management Plan. In this interview, the current situation and potentials of the basin were discussed. After the analyses and literature study, expert opinion was used to determine the most appropriate strategies for the basin. Results indicated that the suitability of the strategies for the basin and ecosystem was taken into consideration. The basin experienced severe dry level drought in 2012, 2013, 2016, and 2019. It was determined that droughts in the basin was not only because of climate change, but also because of improper irrigation techniques, lack of technological systems and public awareness in the basin. In order to reduce the effects of these causes on the drought, practicable resilience strategies have been determined. Strategies determined after the method applied in the selected area in this study are believed make important contributions to the development of the framework of studies in the field of drought. For this reason, the results of the study have the potential to contribute theoretically in terms of drought analysis and practically in terms of the applicability of resilience strategies. If strategies are implemented in accordance with these contributions, it is expected that Lake Van Basin will be less vulnerable to drought risks and more resilient to drought.

Keywords: Drought, Lake Van Basin, Standardized Precipitation Index (SPI), Geographical Information Systems (GIS), Resilience Strategies.

\footnotetext{
${ }^{1}$ Graduate School of Natural and Applied Sciences, Departmen of City and Regional Planning, Gazi University, Ankara

2 Faculty of Architecture, Department of City and Regional Planning, Gazi University, Ankara

* Corresponding author: ozerbuse@outlook.com.tr

Gönderim Tarihi / Received Date: 14.02.2021

Kabul Tarihi / Accepted Date: 09.12.2021
} 


\section{Kuraklık Analizi ve Dirençlilik Stratejileri: Van Gölü Havzası Örneği}

\section{Öz}

Kuraklık, her zaman diğer doğal afetlerden daha yavaş ilerleyen ve geç farkedilen bir doğal afet olmuştur. Yağışların azalmasıyla başlamış ve tüm insan faaliyetlerini etkilemiştir. Artan iklim değişikliğinin etkileri ve geçmiş kuraklıklara bakılarak gelecekte kuraklık yaşanmasının kaçınılmaz olduğu kesinleşmiştir. Günümüze kadar Türkiye de dahil olmak üzere pek çok ülke kuraklığı deneyimlemiştir. Ülkemizde son yıllarda farklı bölge ve havzalarda kuraklığı belgeleyen çeşitli yayınlar ortaya çıkmıştır; ancak geniş tarım alanlarına sahip olan Van Gölü Havzası'nda kuraklık analizi ve devamındaki stratejileri sunan bir çalışma bulunmamaktadır. $\mathrm{Bu}$ çalışmanın amacı, Van Gölü Havzası'nda geçmiş yıllarda yaşanan meteorolojik kuraklıklarının ortaya çıkarılması ve bu kuraklıklara havzanın özelliklerine bakılarak uygun dirençilik stratejilerinin belirlenmesidir. Bu amaçla, geçmiş meteorolojik kuraklıkları tespit etmek ve kuraklık değerlerini hesaplamak için bu çalışmada Standardize Yağış İndeksi (SPI) kullanılmıştır. Mekansal analizler, ArcGIS yazılımı kullanılarak Ters Mesafe Ağırlıkı (IDW) enterpolasyon yöntemiyle hazırlanarak, 2010-2019 yılları arasındaki her yıl için oluşturulan analziler değerlendirilmiştir.

Van Gölü Havzası Kuraklık Yönetim Planı'nda proje uzmanı olarak görev yapmış ilgili uzman ile online röportaj yapılmıştır. Bu röportajda havzanın mevcut durumu ve potansiyelleri tartışılmıştır. Analizler ve literatür çalışması sonrasında havzaya en uygun stratejilerin belirlenmesi için uzman görüşünden yararlanılmıştır. Stratejiler belirlenirken havza ve ekosisteme uygunluğu dikkate alınmıştır. Havzada 2012, 2013, 2016 ve 2019 yıllarında şiddetli kuraklık seviyesinde kuraklık olduğu belirlenmiştir. Havzada yaşanan kuraklıkların sebebinin sadece iklim değişikliği değil tarımda kullanılan suyun, yanlış sulama tekniklerinin, teknolojik sistemlerin havzada eksikliğinin ve halk bilincinin de etkili olduğu tespit edilmiştir. Bu sebeplerin kuraklık üzerindeki etkilerinin azaltılması için havzaya uygulanabilir dirençlilik stratejileri belirlenmiştir. Çalışmanın gerçekleştirildiği Van Gölü Havzası'nda uygulanan yöntem ve geliştirilen stratejilerle birlikte, kuraklıkla ilgil yapılan çalışmaların çerçevesinin geliştirilmesine önemli katkılar sağlayacağı düşünülmektedir. Bu nedenle bu çalışmanın sonuçları, kuraklık analizi bakımından teoride, stratejilerin uygulanması bakımından ise pratiğe katkı sağlama potansiyeline sahiptir. Bu katkılarla uyumlu stratejiler uygulanırsa, Van Gölü Havzası'nın kuraklığa karşı daha dirençli ve kuraklıklık risklerine karşı daha az etkilenebilir olacağı beklenmektedir.

Anahtar Kelimeler : Kuraklık, Van Gölü Havzası, Standartlaştırılmış Yağış İndeksi (SPI), Coğrafi Bilgi Sistemleri (CBS), Dirençlilik Stratejileri.

\section{Introduction}

The increase in the world population day by day, the development of all sectors, the continuous increase in the water need affect the whole ecosystem and augments the demand for already scarce water resources. For this reason, the probability of cities and even countries to encounter drought that advances slowly and differently from other natural disasters increases. Wilhite (2000) explains the difference of drought from other natural disasters in several ways.

The first is that drought is a cumulative natural disaster, its beginning and end are difficult to predict. The second is that although drought has many different definitions, there is no 
universal definition. However, at this point, we can talk about the general definition of drought made by The World Meteorological Organization (WMO, 1986): "drought means a sustained, extended deficiency in precipitation." However, only the decline in precipitation is not effective in the formation of drought. Other reasons for drought occurrence are precipitation (amount, regime, time distribution and intensity), evapotranspiration defined by the solar radiation, air temperature, water vapor pressure and wind velocity, soil and vegetation cover characteristics (e.g. water retention capacity, infiltrability of the soil) (Tsakiris And Vangelis, 2004). It was defined and calculated differently in different disciplines due to the use of different reasons for the occurrence of drought. The third is that drought affects geographical areas, not structures. The consequences of these geographical effects are enormous. It starts with the decrease in precipitation and continues as chain effects.

Meteorological drought starts with the lack of precipitation and causes agricultural drought (Wilhite, 2000). Crop loss occurs as a result of the inability to meet the water needs of the plant due to meteorological conditions (Wilhite and Glantz, 1987). Hydrological droughts are associated with recognizing the lack of precipitation on water surfaces. The depletion of surface and groundwater reserves and the lower than normal flow define hydrological drought (Türkeş, 2017). Recharging water resources can take months or even years, which affects many sectors including public water supplies, hydroelectric power production, recreation, transportation, and agriculture (Wilhite, 2000). The last stage is the stage in which drought amplifies its effects and economic, social and environmental consequences occur. Considering that the supply of many economic products such as water, food and hydroelectric power plants depends on weather conditions, it affects the production and consumption activities of the society. When there is a socioeconomic drought, production cannot meet the demand (Kadıoğlu, 2008). Türkeş (2012) does not use agricultural and hydrological distinctions and defines drought as "a water deficit that occurs as a result of the existence of natural water used by various systems on Earth, occurring over a certain period and on a regional scale below the long-term average or normal." According to him, drought is characterized by the components of severity, duration, and spread (Türkeş, 2017).

Due to increasing water need and decreasing water resources, most continents have experienced frequent droughts in the last three decades (Mishra and Singh, 2010). Turkey is one of the countries experiencing drought. The severest droughts in large areas of Turkey occured in the periods of 1971-1974, 1983-1984, 1989-1990, 1996-2001, and 2007-2008. The consequences of the drought during these periods affected irrigation, drinking water, hydrological systems and activities. During the 2007-2008 drought period, underground and surface water resources weakened, causing long-term water cuts in metropolitan such as Ankara and Istanbul (Türkeş, 2012). These effects were highly effective and noticeable due to the vulnerability of the cities.

The effects of drought continue to increase unless resilience is built in societies with the reduction of water resources. According to Walker et al.(2004) resilience is "the capacity of a system to absorb disturbance and reorganize while undergoing change to still retain essentially the same function, structure, identity, and feedback-in other words, stay in the same basin of attraction." A resilient society can absorb disturbances and adapt quickly to changes, but in a vulnerable system, even small changes may be devastating (Folke et al. 2002). It is necessary to be prepared for future risks, both known and unknown. If not, the drought manifests itself as a socioeconomic drought on the last level and disrupts the daily operation. If the durability is increased, the needs will continue to be met. In order to do this, there is a need for the determination and implementation of resilience strategies and an effective drought management. Jha et al. (2013) stated that resilience should first be provided in four areas: infrastructural, institutional, economic, social. For them, the resilience of the infrastructure means the responsiveness and recovery capacity of a community. Institutional 
resilience is important for management both before and after drought occurs. Economic resilience is affected very quickly after a drought occurs, it is significant in terms of savings before the disaster and the ability to operate after a disaster. In all natural disasters, disadvantaged groups are affected first, and they suffer the most. Social resilience should be provided both in this respect and in order to ensure citizenship and unity awareness.

Resilience against drought should be built in the Lake Van Basin. In the first phase of this study, past droughts were analyzed to create a resilient basin and to mitigate the effects of drought. The drought strategies obtained by the literature review were discussed with an expert and the most appropriate strategies and solutions were developed for the Van Lake Basin. It was believed that these strategies were suitable and applicable to the basin and will create a resilience network in the basin.

The difference of this study from other drought studies was the determination of strategies based on the drought level of the study area in the past years. In addition, an in-depth interview was conducted with the relevant expert for the compatibility of these strategies. The most appropriate strategies were determined for the Van Lake Basin, which contains Turkey's largest lake and is a closed basin. Since both the study analysis and the strategies are based on the literature and expert opinion, it is expected that these features, which are combined specifically for the basin, will contribute to the literature.

\section{Study Area And Research Methodology}

\subsection{Study Area}

Study area is Lake Van Basin, which is one of Turkey's 26 hydrological basins. Lake Van Basin is located between $37^{\circ} 55^{\prime}-39^{\circ} 24^{\prime}$ north latitude and $42^{\circ} 05-44^{\circ} 22$ 'east longitude. Lake Van is the largest lake in Turkey in terms of area. The rivers of the Lake Van Basin flow into Lake Van, not into the sea, and so it is called the closed basin. The rivers located in the south of Van province reach the Persian Gulf and the rivers in the east reach Iran. The location of the Lake Van Basin among other basins is given in Figure 1. There are many lakes and rivers within this area, including Lake Van, Lake Erçek, Nemrut Crater Lake, Turna Lake, Akgöl and Aygır Lake.

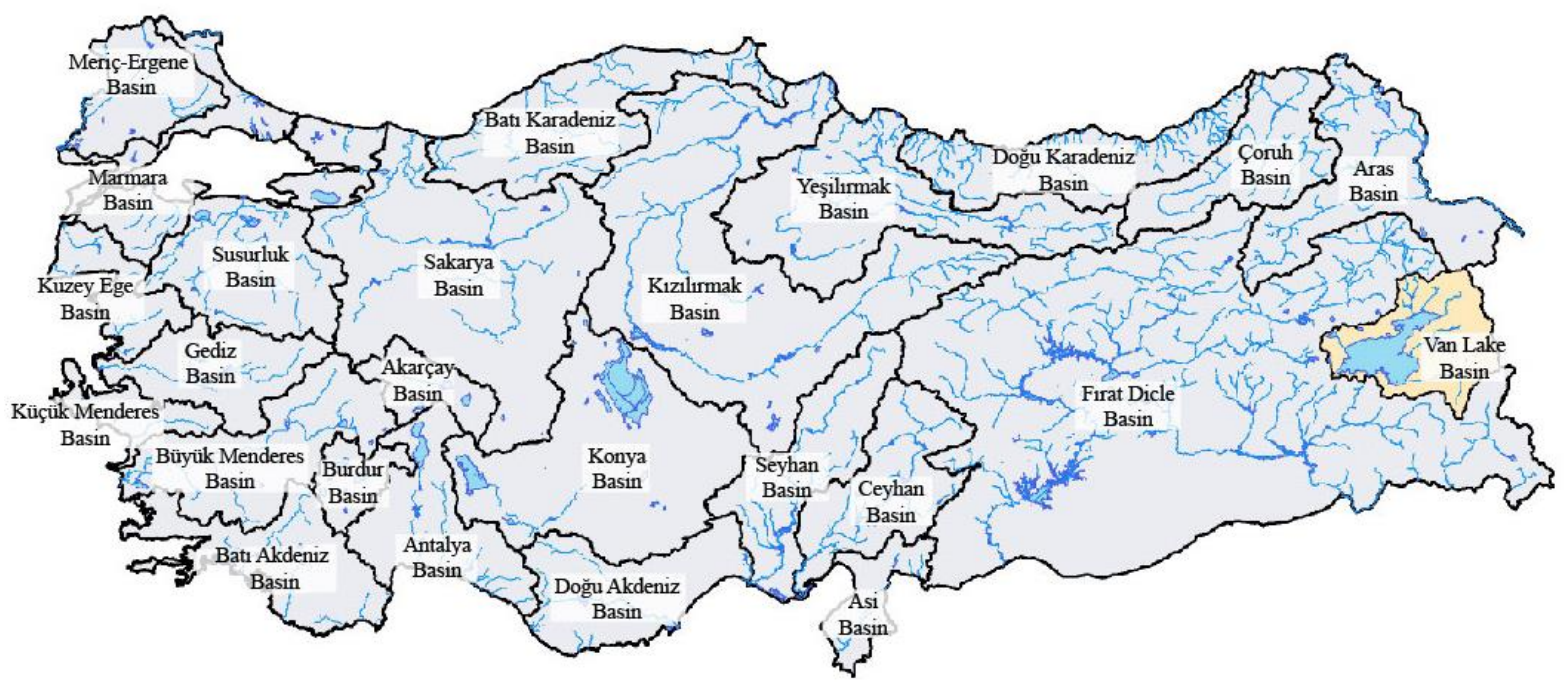

Figure 1: Location of the Lake Van Basin 
Lake Van Basin consists of Muradiye, Ercis, Caldıran, Ozalp, Gurpınar, Edremit, Tusba, Ipekyolu and Gevas sub province of Van and Tatvan, Ahlat, and Adilcevaz subprovince of Bitlis. Sub province boundaries in the basin are shown in Figure 2, Tusba and Ipekyolu district are shown as Merkes sub province. The populations of the sub provinces and their rates in the basin are shown in Table 1. Accordingly, as seen in Figure 2, Van forms the largest area in the basin. The total population within the basin is $1,217,013$. Van constitutes $86.49 \%$ of the basin's population and Bitlis constitutes $13.51 \%$ (Table 1).

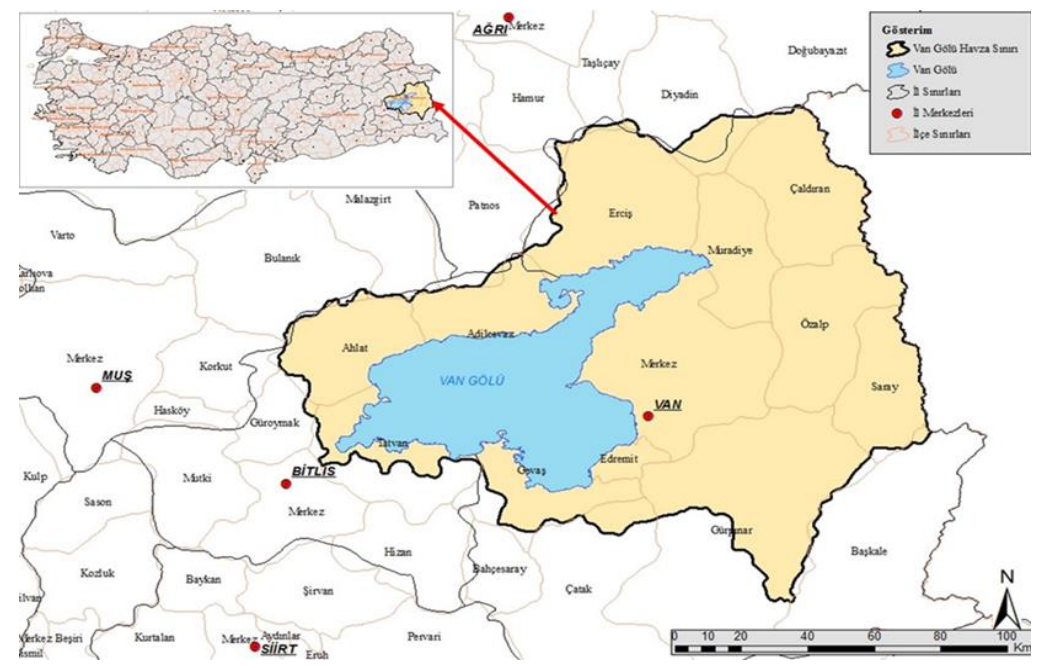

Figure 2: Subprovinces in Lake Van Basin

(Lake Van Drought Management Plan, 2018)

Table 1: Populations of The Districts and Their Ratio Within the Basin (TUIK, 2020, Address Based Population Registration System)

\begin{tabular}{|c|c|c|c|}
\hline Province & Subprovince & Population & $\begin{array}{l}\text { Ratio of Population of Province in The } \\
\text { Basin to Population of The Basin }\end{array}$ \\
\hline \multirow{10}{*}{ Van } & Ipekyolu & 326,007 & \multirow{10}{*}{$86.49 \%$} \\
\hline & Tusba & 162,848 & \\
\hline & Caldıran & 62,530 & \\
\hline & Edremit & 127,505 & \\
\hline & Ercis & 175,108 & \\
\hline & Gevas & 28,235 & \\
\hline & Gürpınar & 34,393 & \\
\hline & Muradiye & 50,206 & \\
\hline & Ozalp & 65,296 & \\
\hline & Saray & 20,498 & \\
\hline \multirow{3}{*}{ Bitlis } & Adilcevaz & 30,499 & \multirow{3}{*}{$13.51 \%$} \\
\hline & Ahlat & 40,699 & \\
\hline & Tatvan & 93,189 & \\
\hline \multicolumn{2}{|c|}{ Lake Van Basin } & $1,217,013$ & $100 \%$ \\
\hline
\end{tabular}

According to Lake Van Basin Drought Management Plan (2018), economy of Van province is based on agriculture and trade. Livestock is important in agricultural activities. The secondranked trade sector includes the trade of agricultural and animal products, industrial products, and construction materials. The economy of Bitlis province depends on agriculture and 
livestock, and the industrial sector has not developed. It is clear that the agriculture and livestock sector has developed in both provinces in the basin; therefore, when drought occurs, the first sector affected will be agriculture and then livestock.

According to the Lake Van Basin Drought Management Plan, water needs will arise in villages in the southeast of the basin at the earliest in 2025, and spatial and quantitative water demandwill increase in the following years. Approximately $62.3 \%$ of the basin population (according to the 2025 population projection) will need drinking water in the years starting from 2025. In 2030, 309 million $\mathrm{m}^{3} /$ year of water will be needed for the irrigation of approximately 3708 hectares of agriculture. These needs are important and vital for the basin that is dependent on a single sector. For this reason, with water levels falling rapidly in an extreme drought, the effects of drought in the basin may be more severe than expected. Lake Van Basin was chosen as the study area because it is based on the agriculture sector, which is the sector that is affected most rapidly by drought, and water needs will begin to emerge in 2025 , which is a very soon.

\subsection{Research Methodology}

In this study, two different methods were employed. Standardized Precipitation Index (SPI) values were calculated using precipitation data as the first method. As a result of these values, the drought levels of the region were determined and then the determined values were mapped with Arcgis software. Another method was an interview with an expert (personal communication, December 12, 2020), who served as a project expert during the process of the Lake Van Basin Drought Management Plan. The aim of this in- depth interview was to learn about drought and its effects, planning and resilience strategies in the basin.

As a result of the interview, detailed information, planning process, effects of drought and the main causes of drought was acquired about the basin. The strategies and practices were discussed that should be implemented in order to prevent the effects of drought in the basin for the future. To sum, insight on the issue was obtained with these two methods used.With the drought analysis, the past and future of the drought in Van Lake Basin were determined. With the interview, the drought situation in the basin was discussed. Strategies implemented in basins or cities in other countries and also those that are suitable for the Lake Van Basin were determined in the literature review.

The first method used in the study was drought calculation and mapping. The monthly average precipitation and temperature data of Lake Van Basin were obtained from the General Directorate of Meteorology. In this study, precipitation data of meteorological stations in the study area between 2010 and 2019 were used to determine the drought in Lake Van Basin. Temperature values between 1990 and 2019 were also used to recognize the basin. Years of complete meteorological measurements were included in the analysis. Data of a total of 7 meteorological observation stations, six stations from Van province and one station from Bitlis province, were used and station locations are given in Figure 3. 

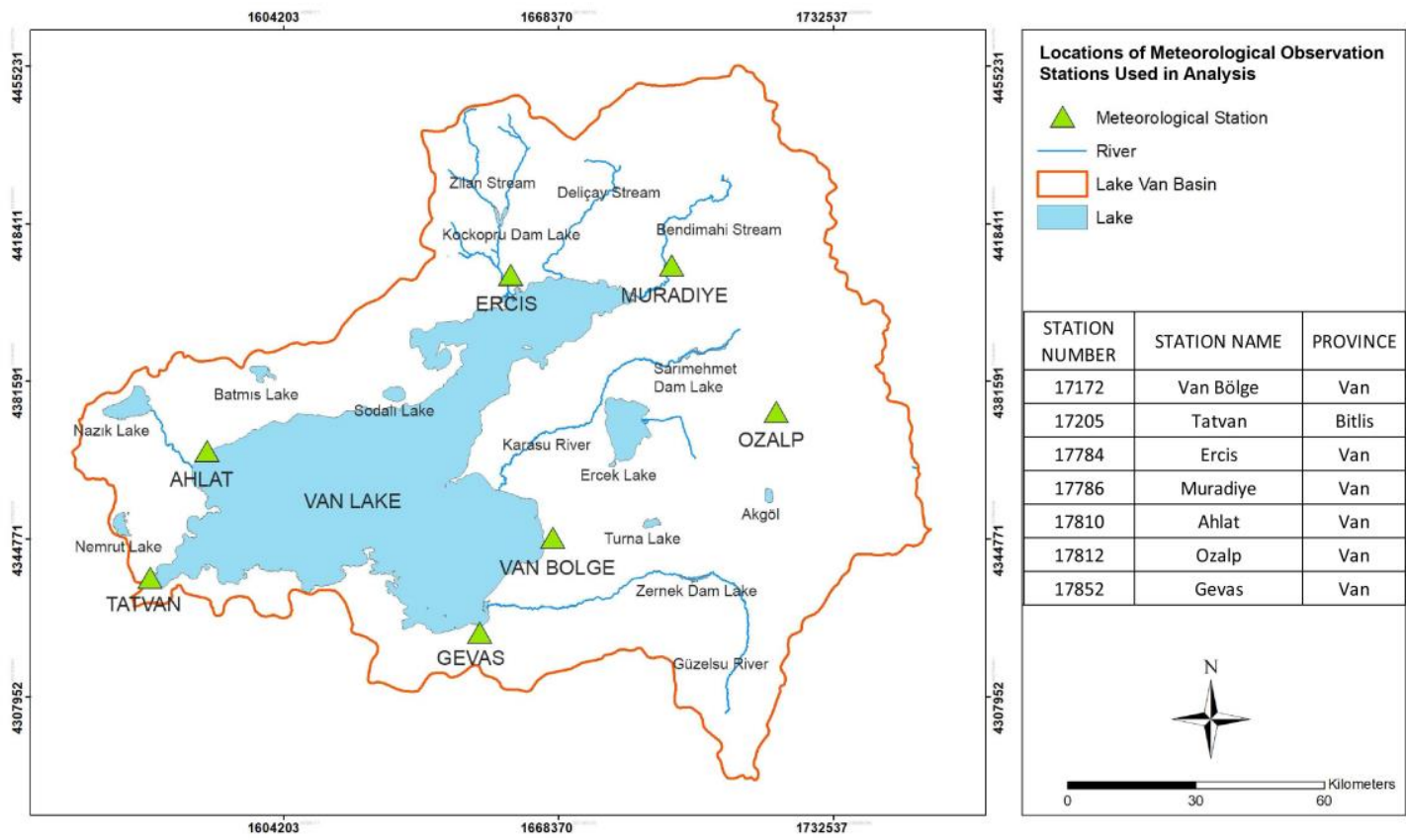

Figure 3: Locations of Meteorological Observation Stations Used in Analysis

Among many different methods for drought analysis, Standardized Precipitation Index (SPI) method was selected and past droughts was determined using the data of seven meteorological observation station. The reason this index was selected is because the calculation process is faster with less data than other indexes. SPI is a drought analysis method based on precipitation values developed by McKee et al. (1993). The Standard Precipitation Index (SPI) is mainly obtained by dividing the difference of precipitation from the average over the specified time period by the standard deviation. It can be calculated for different time periods such as 3, 6, 9, 12, 24 months (McKee et al. 1993). The formula used by the Meteorological Service (Drought and Classification, 2020) is as follows:

$$
\mathrm{SPI}=(X i-\overline{X i}) / \sigma)
$$

The explanation of this formula is as follows; SPI: Standardized Precipitation Index, $X i$ : actual precipitation amount $(\mathrm{mm}), \overline{X i}$ : average precipitation $(\mathrm{mm})$ for the selected time interval for each station and $\sigma$ : refers to the standard deviation of values for each station within the time interval. In this study, drought categories in Table 2 were used. The periods in which the SPI value falls below zero are considered as dry periods, and values above 0 are considered normal and wet periods.

Table 2: SPI Values and Drought Categories (McKee et al., 1993; Giddins et al., 2005)

\begin{tabular}{ll}
\hline \hline SPI Values & Drought Categories \\
\hline 2.00 and above & Extreme wet \\
1.99 to 1.50 & Severe wet \\
1.49 to 1.00 & Moderate wet \\
0.99 to 0 & Normal \\
-0.99 to 0 & Mild drought \\
-1.00 to -1.49 & Moderate drought \\
-1.50 to -1.99 & Severe drought \\
-2.00 and less & Extreme drought \\
\hline \hline
\end{tabular}


Another reason why SPI analysis was chosen is that it is easy to implement. The SPI method has been widely used in meteorological drought analyses in Turkey. These analyses differed from each other in scale. It is possible to classify the meteorological drought analyses made with the SPI method as cities, basins, and regions.

It has been seen in the literature that SPI analysis is mostly used to detect droughts of cities. Antalya, Bursa, Gaziantep, Isparta, Şanlıurfa, Karaman, Kırıkkale, Konya, Muğla, Samsun, and Şanlıurfa meteorological drought analyses were performed in different time periods using meteorological station data. (Dinç et al., 2016, Bacanlı and Kargı, 2019, Taylan and Bahşi, 2021, Keskin et al., 2007, Uçar et al., 2019, İrcan and Duman, 2021, Karaman Yürekli and Anlı, 2008, Oğuztürk and Yıldız, 2014, Atmaca, 2011, Oğuz et al., 2021, Beden et al., 2014, Gümüş et al., 2016)

Since Lake Van Basin was chosen as the study area, drought studies that employed the SPI method in other basins were reviewed in the literature. Hınıs (2008) made short-term and longterm drought determinations by using meteorology stations in Konya Closed Basin. Sarış and Gedik (2021) also conducted a drought analysis with the SPI method between 1930 and 2019 in Konya Closed Basin and mapped it with the Kriging method. The study offered measures that can be taken to prevent drought.

Oğuztürk (2010) analyzed the drought between 1950-2007 in Kızılırmak Basin and found that the drought has increased in recent years. It was emphasized that there are many important agricultural areas in Kızılırmak Basin and there are more than 10 important dams. For this reason, drought determination and resource planning for the basin play an important role. Arslan et al. (2016) also analyzed the drought that occurred in Kızılırmak between 1973 and 2013 with the SPI method. Unlike Oğuztürk (2010), they determined the drought in 60-month periods. Yetmen (2015) made a drought assessment for Lake Basin in 1975-2008. In this study, in addition to the SPI analysis, the relationship of the dry periods in Lake Van Basin with the North Atlantic Oscillation (NOS) indices was measured. As a result of the analysis, the longest and driest period at Tatvan station was between 1996-2002 and it was found to be between 1998-2002 at Van station.

In addition, the North Atlantic Oscillation was found to have an effect on drought trends. Şener and Şener (2021) conducted a drought analysis for Burdur Lake Basin using the SPI and CZI index. After the analysis, it was mapped with the IDW interpolation method using point data. It has been concluded that the amount of precipitation falling on the Burdur Lake Basin has decreased significantly, especially in recent years. In the Seyhan Basin, Keskiner et al. (2016) performed a drought analysis using the SPI method with the monthly and annual total precipitation series of 1950-2006. In the research, the Digital Elevation Model (DEM) map of the Seyhan Basin with a resolution of $100 \times 100$ meters was used. A drought analysis covering the years 1970-2016 in Çorak Lake Basin was carried out by Şener and Şener (2019) using SPI and Geographic Information Systems. It was concluded in the study that 6 years were severely dry. It was mapped using the IDW interpolation method in ArcGIS software. Drought analysis with SPI in Asi Basin (Dikici, 2019), Kumdere Basin (Bakanoğulları, 2020), Yukarı Gediz Basin (Kumanlıoğlu and Fistikoğlu, 2019), Susurluk Büyük Akarsu Basin (Yüceerim et al., 2019), was done between long-term years.

It is seen that the studies carried out on a regional scale are carried out for almost every region. Çaldağ et al. (2004) analyzed the Thrace region with the SPI method and concluded that there was severe drought in the entire region except for Istanbul in 2000 and 2001. Sırdaş and Şen (2003) made a drought analysis for Istanbul, Edirne, Tekirdağ, and Kırklareli regions and mapped them with the Kriging method. Yeğnidemir (2005) reached the drought 
characteristics of 28 meteorological stations in the Central Anatolia region using the data between 1953 and 2003. In the continuation of the study, drought maps were created with the Kriging method. Topçuoğlu et al. (2008), conducted a short and long-term drought analysis in the Aegean Region and concluded that there was a drought throughout the region in different years and it was more severe in the coastal regions. In the same region, Pamuk et al. (2004) also conducted a drought analysis using the data of selected meteorological stations with longterm precipitation measurements. Fidan (2011) conducted a drought analysis with the SPI method using the data of meteorological stations in the Eastern Mediterranean Region and then made a drought modeling. Çelik et al. (2018) made a drought analysis of the Eastern Anatolia Region using the data between 1967-2017. They found that there were serious seasonal drought trends in Malatya, Elazig, Tunceli, Van and Kars. On the other hand, in the study by Özfidaner et al. (2020), 40 years of precipitation data obtained from stations in the Southeastern Anatolia Region were analyzed with SPI and determined the drought degrees.

In this study, station-based SPI values were calculated from the precipitation data of meteorology stations in Lake Van basin, similar to the studies in the literature. Then, these values were analyzed with ArcGIS software by Inverse Distance Weighted (IDW) interpolation method and analyses were made for each year separately with this method.It was used because it is a suitable method for classifying drought categories and spatial analysis.

According to Aydın and Çiçek (2013) "In the IDW method, it is assumed that the connection and similarity between two points are proportional to the distance between them. It is a frequently used method in spatial precipitation interpolation." The values of the unknown point are estimated mathematically through the known point values. In this estimation, in the prediction of the unknown point, the distant points have less affect on the value than the close points (Franke ve Nielson, 1980). Agnew and Palutikov (2000), Portalés et al. (2010), and Doğru et al. (2011) emphasized that more accurate results would be obtained when geographic information (eg, longitude and latitude) was included in interpolation methods. In this study, while applying the IDW method to meteorological stations, care was taken to ensure that the stations were in the correct positions with latitude and longitude information. For this reason, it was thought that more accurate results would be obtained from the analysis and it would affect the appropriate strategies.

Borges et al. (2016) compared spatial interpolation methods such as IDW, spline, OK, CoOK and DUK after visual analysis of the spatial distribution of precipitation. In this comparison, they also took into account geographical factors and concluded that topography is especially effective in the distribution of precipitation. Goovaerts (2000) and Haberlandt (2007) likewise emphasized the importance of topography in these analyses. The importance of topography was ignored in the IDW method used in this study. Topography affected the amount of precipitation and indirectly affected the analysis as it was calculated based on the amount of precipitation falling when performing the drought analysis. This is the most important missing of the IDW analysis in the drought analysis.

In the analysis, the effect of drought severity in relation to the distance between stations was assessed. Calculation of SPI values and creation of maps with IDW interpolation method were carried out in order to determine the past droughts experienced in the basin and the drought situation was evaluated considering the characteristics of the basin. It was important to understand the severity and spatial effect of the drought.

\section{Analysis Findings and Discussion}

In this study, the data of seven meteorological observation stations in the basin were examined. The average precipitation of each meteorological observation station is shown in 
Figure 4 according to precipitation data for the 2010-2019 time period as the many years of below average precipitation indicated the beginning of drought. Accordingly, it was determined that the highest average precipitation was in Tatvan station and the lowest in Ozalp station besides it was observed that precipitation at all stations was below the average precipitation at least 3 years.
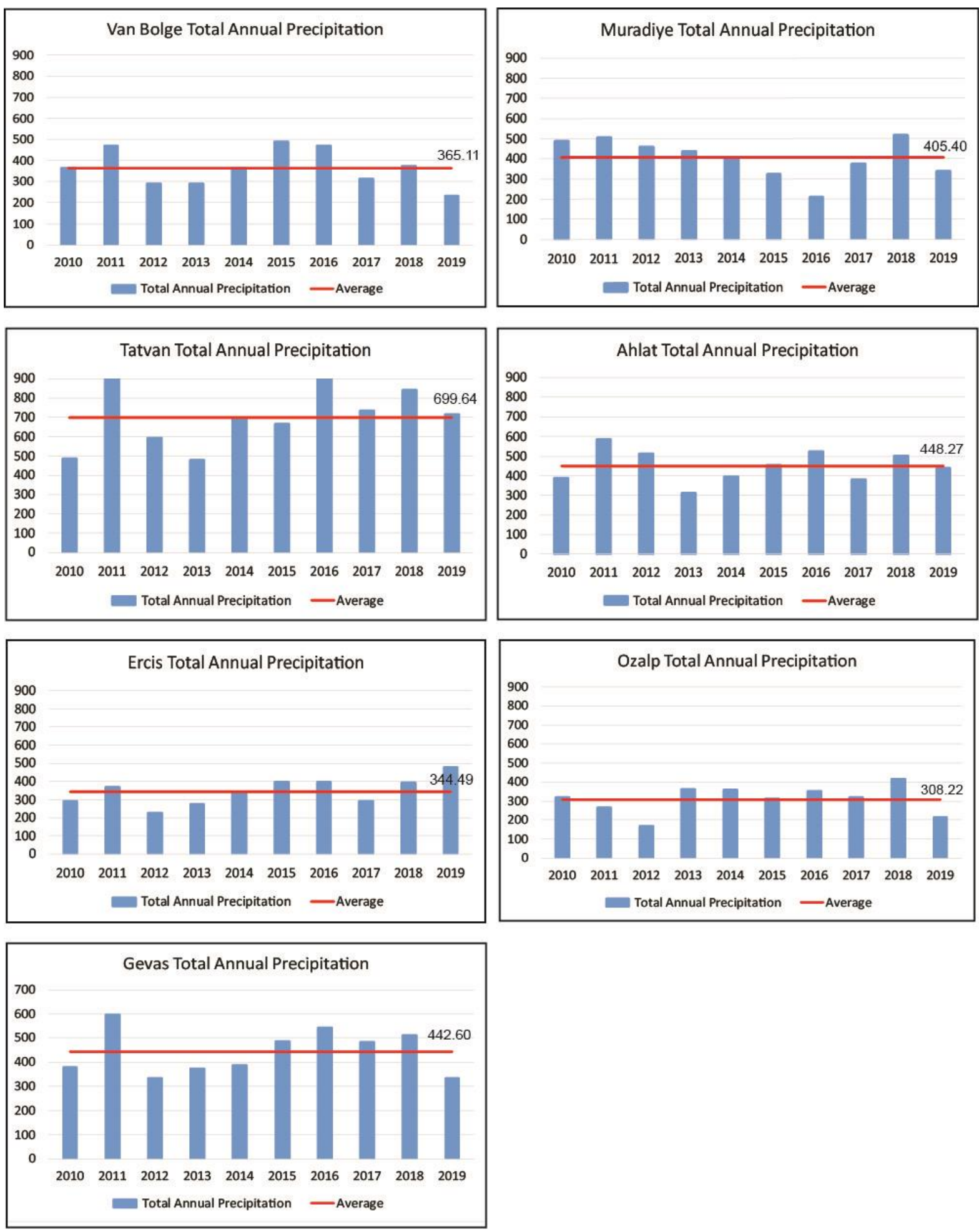

Figure 4: Annual Total Precipitation of Meteorological Stations 
The precipitation distribution of the basin was prepared by using IDW interpolation method in ArcGIS software using the average annual total precipitation values in Figure 5. Average precipitation throughout the basin is $430.5 \mathrm{~mm}$. The region with Tatvan meteorological station received precipitation in the range of $656-700 \mathrm{~mm}$, while the region with Ozalp and Ercis stations received precipitation in the range of 300-355 ( $\mathrm{mm})$. Accordingly, the east and north of the basin receive relatively less precipitation, while the west of the basin receives more precipitation than the average of the basin.
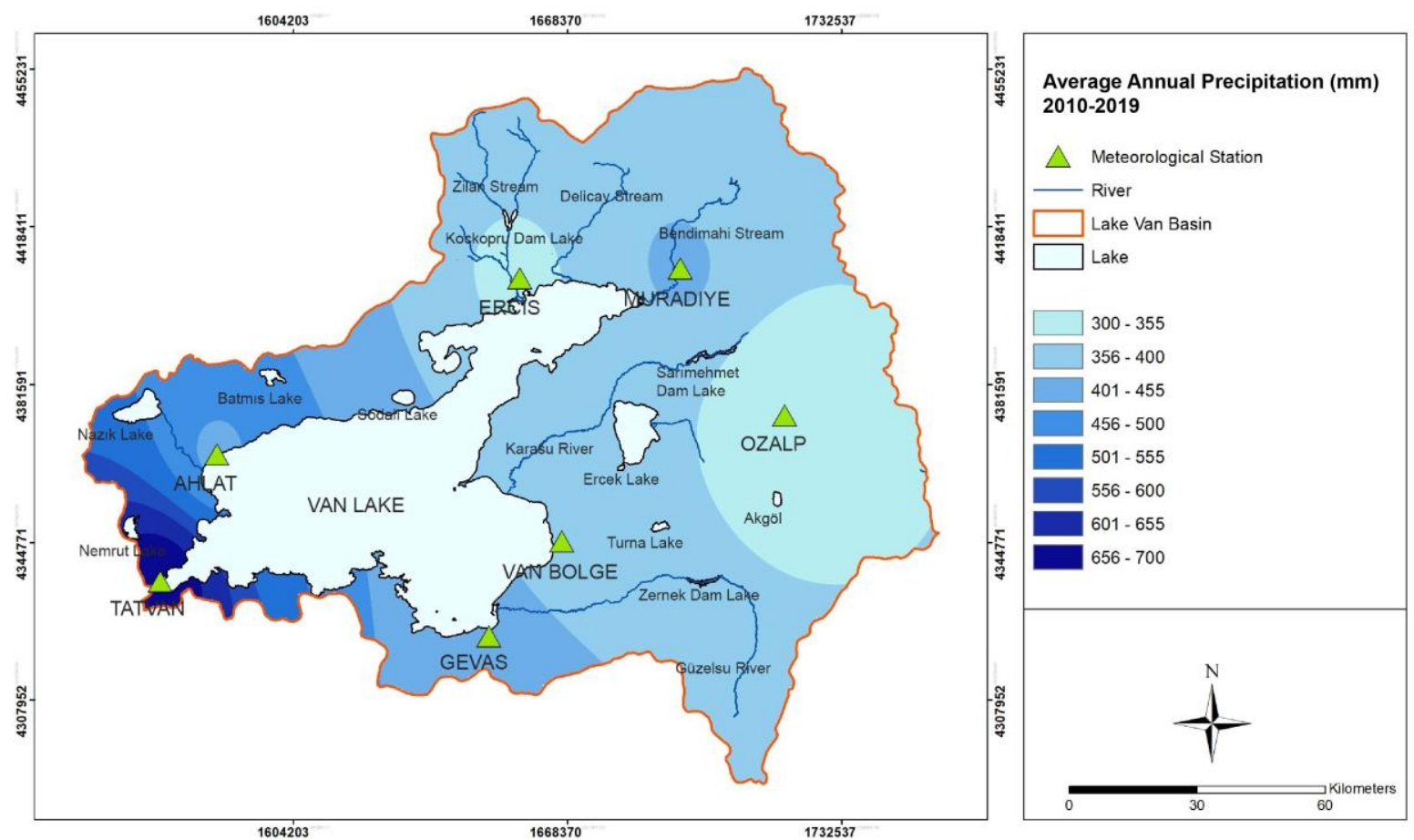

Figure 5: Average Annual Precipitation (mm)

The temperature distribution of the basin was analyzed with the average annual temperature values measured at meteorology observation stations. The temperature of Lake Van Basin is shown in Figure 6 according to the average between 1990-2019. When Figure 6 was examined, it was seen that the temperature differences was insignificant in the basin but the temperature in the east of the basin was lower than the entire basin. When Figure 5 and Figure 6 are examined, the following situation draws attention: Ozalp station received less precipitation than other stations as seen in Figure 5 and had a lower temperature than others as seen in Figure 6.

The lowest annual average temperature of the basin was $6.3^{\circ} \mathrm{C}$ at Ozalp station, and the highest temperature was measured at $9.87^{\circ} \mathrm{C}$ at Van Bolge station. The reason for the highest average temperature in Van Region station was that the station is in the Van city settlement. 


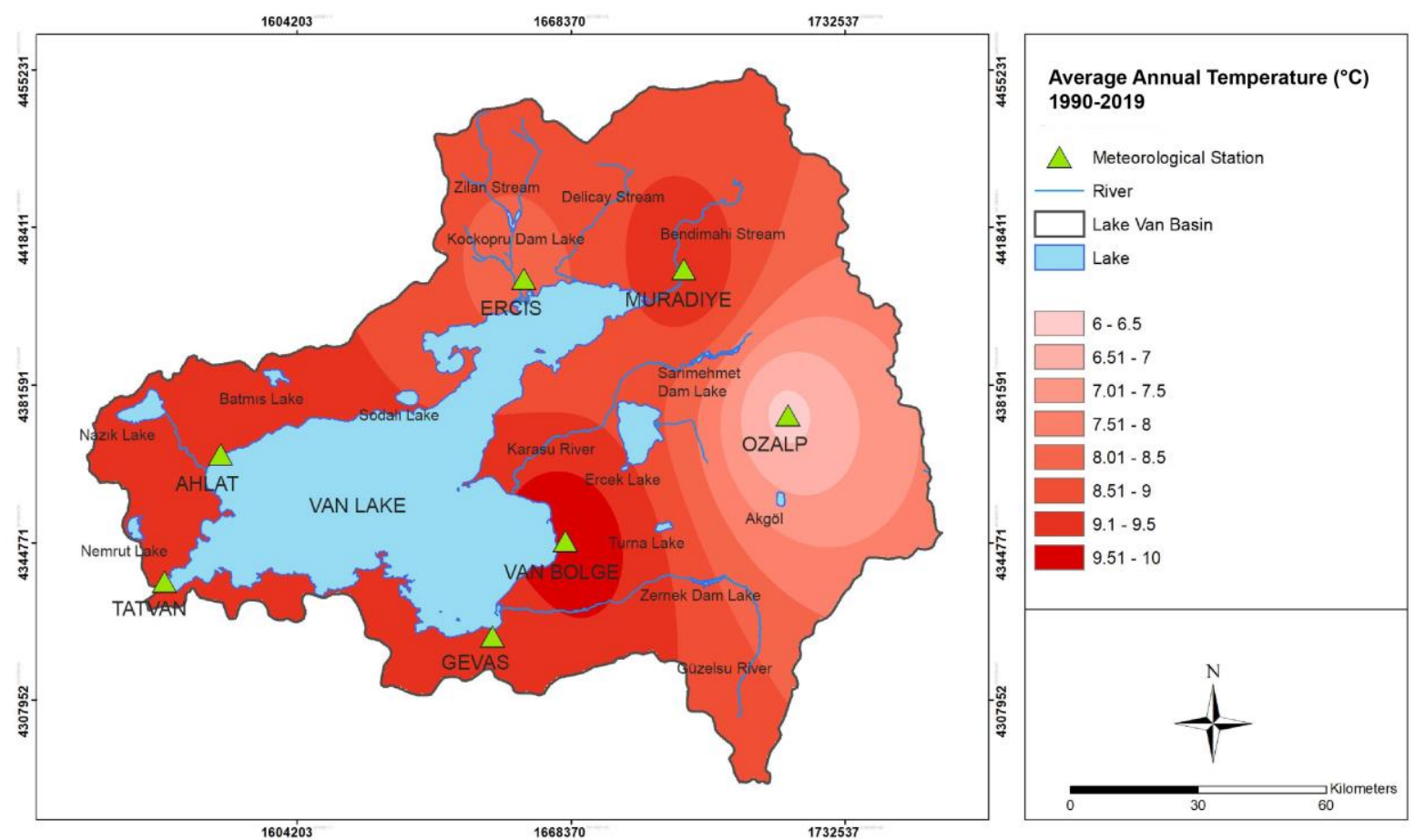

Figure 6: Average Annual Temperature $\left({ }^{\circ} \mathrm{C}\right)$

The drought values of Van Region, Tatvan, Ercis, Muradiye, Ahlat, Ozalp, Gevas stations were found using meteorological station data, and SPI index and it was then mapped for each year by IDW interpolation analysis. In the drought maps in Figure 7, the basin was determined to be dry at the level of severe dry in 2012, 2013 and 2016, and wet at the level of severe wet in 2011. Unlike other years, 2019 included both dry and wet levels. It was observed that the southeast of the basin was dry at the severe drought level, and the north of the basin was wet at the severe wet level. Areas that experienced extreme drought and extreme wet level was not seen between the years studied.

In 2010, the first year of the analysis, it is possible to say that the basin was mostly at normal levels. In 2010, the first year of the analysis, it was at the moderate dry level only at Tatvan station, but it is possible to say that the basin is mostly at the normal level. Among all the years analyzed, 2011 was the wettest year. The western and southwestern areas of the basin received precipitation at the level of severe wet, and it was rainy at normal levels for more than half of the basin. It was observed that drought was experienced in 2012 and 2013, consecutively. The driest year was 2012 and in this year, wider areas of the basin were at the moderate drought and severe drought levels rather than the other years. In 2013, there was drought in the Ahlat station at the moderate dry and severe dry level, and for more than half of the basin, it continued at a normal level. It was seen that 2014 was at normal and mild drought levels for the whole basin. This year it rained at levels that cannot be called a drought. It was observed that 2015 was wetter than 2014 and the drought level was lower. In 2016, severe drought level was observed in the north of the basin, while it was normal and wet for the rest of the basin. For more than half of the basin, 2017 was at the mild drought level and normal level. The year 2018, unlike other years, never experienced the level of mild drought and more than half of the basin was wet at normal level and moderate wet level for the rest of the basin. This year is the only year in the basin without a lack of precipitation in all years. In contrast to other years, both severe drought and severe wet levels were seen in 2019. 

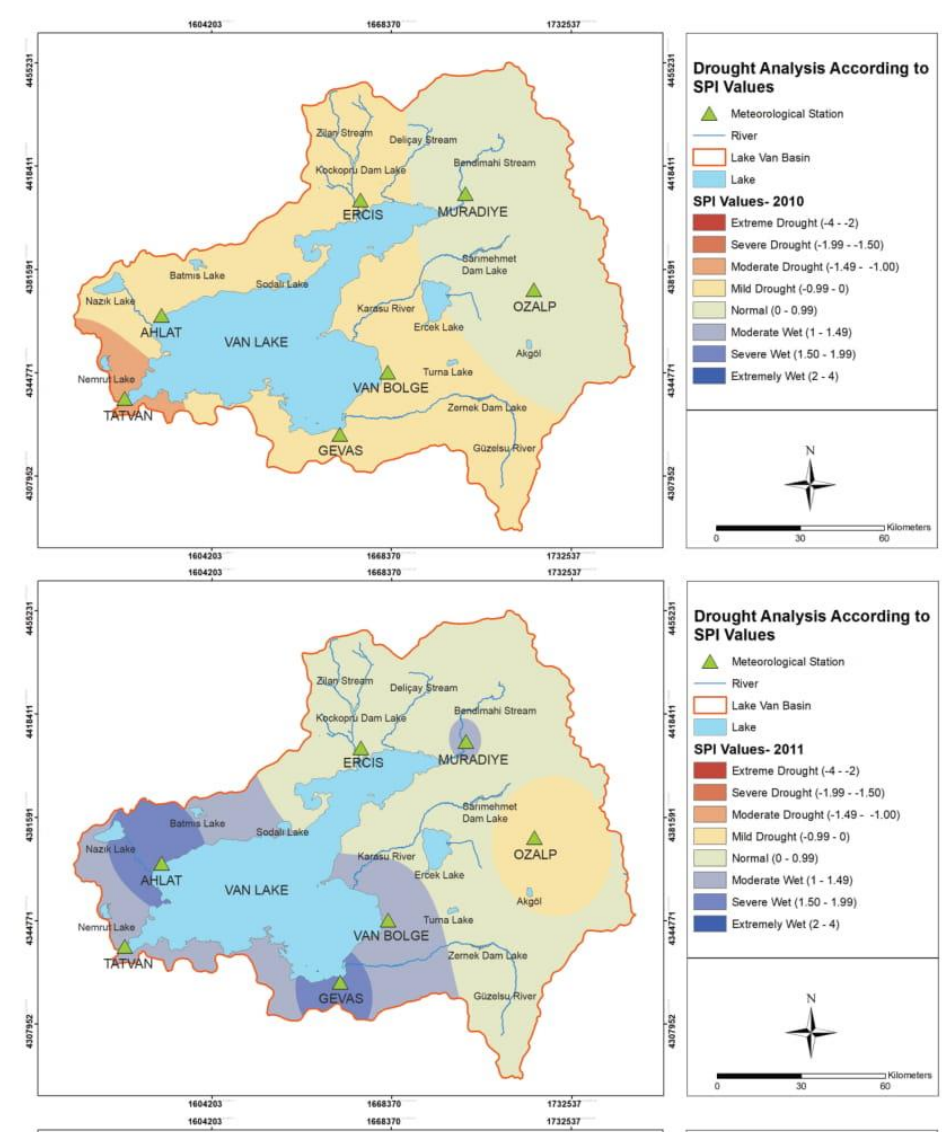

Drought Analysis According to Drought An
SPI Values
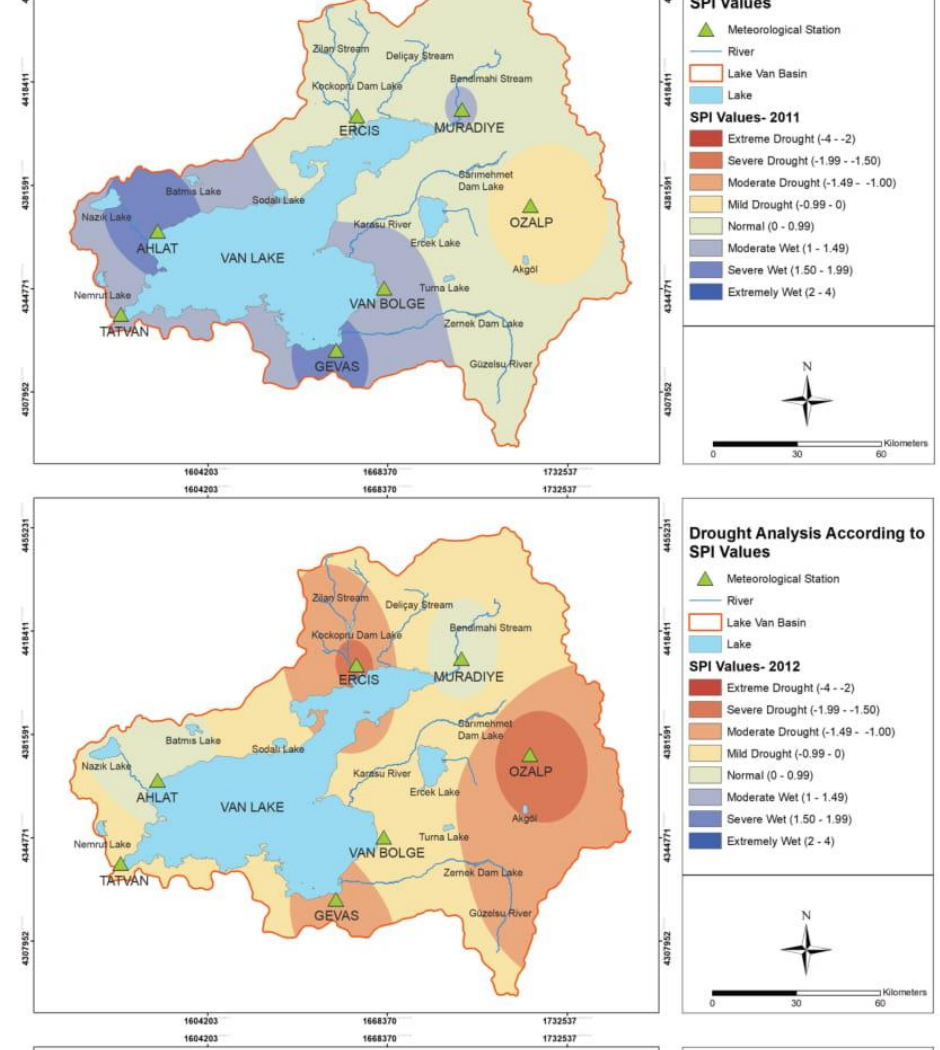
Drought Analysis According to
SPI Values

$\triangle$ Neteorilogical Station

L River

LPI Values- 2012

SPI Values- 2012

Severe Prought $(-1.99 \cdots 1.50)$

Moderate Prought $(-1.49 \cdot 1.1 .00)$

Moderate Drought (-1.4.

Normal (0. 0.99)

Moderate Wet (1-1.49)
Severe Wet 1 150-199)

Extoment $1.50-1.090$
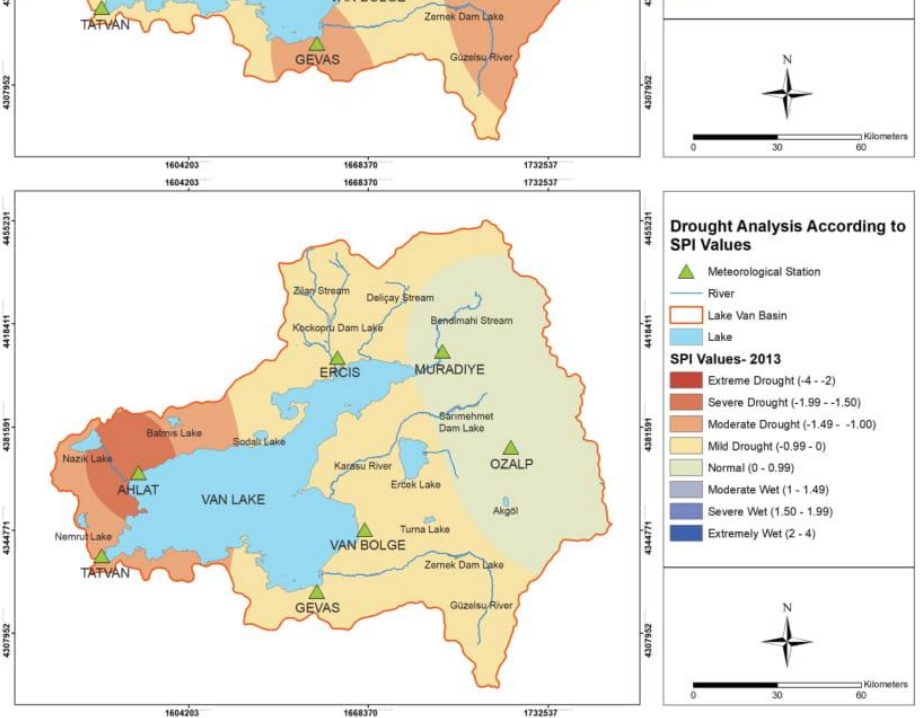

Figure 7: Drought Analysis (2010-2013) 


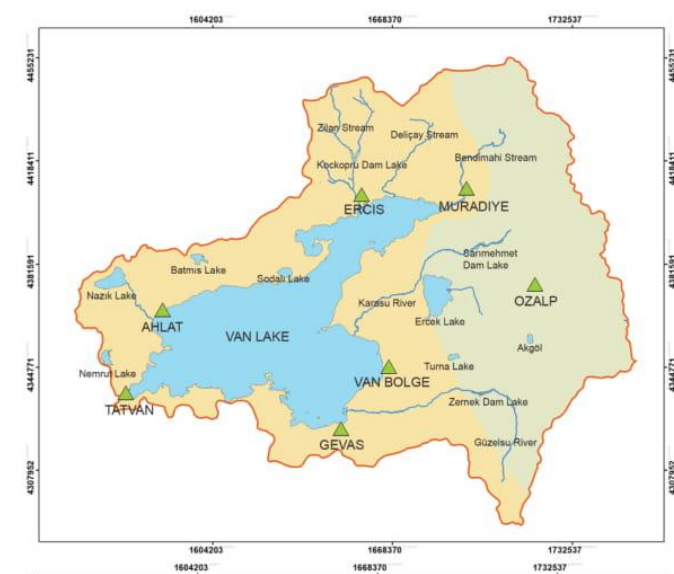

Drought Analysis According to SPI Values

$\triangle$ Meteorological Station

$\square$ Lake Van Bas

SPI Lake 2014

SPI Values- 2014

Extreme Drought (-4-2) Severe Drought (-1.99-1.1.50)

Moderate Drought (-1.49 - 1.00

Mild Drought (-0.99- -

Moderate Wet (1-1.49)

Sovere Wet (1.50 - 1.99)

Extremely Wet $(2-4)$

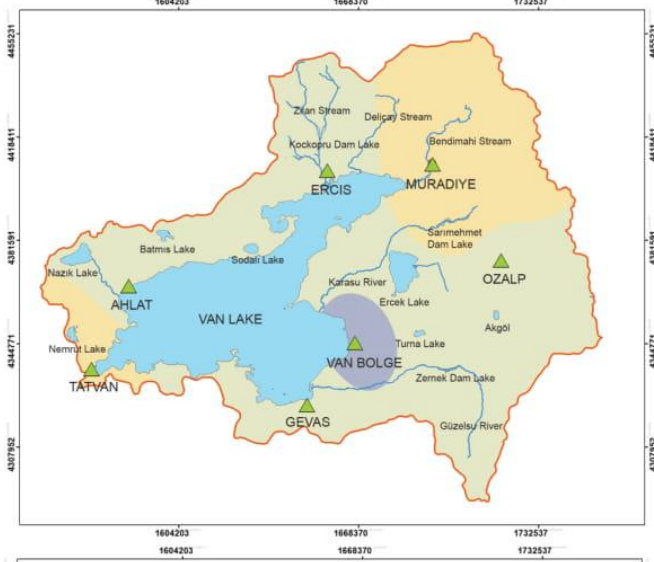
Drought A
SPI Values

$\Delta$ Meteorological Station

$\square$ Lake Van Basin
Lake

SPI Values- 201

Extreme Drought (-4-2) Severe Drought $(-1.99 \cdot \cdots 1.50)$

Moderate Drought $(-1.49-1.00$

Moderate orought $(-1.49 \cdot 10$.

Normal (0-0.99)

Moderate Wet (1-1.49

Extremely Wet (2-4)

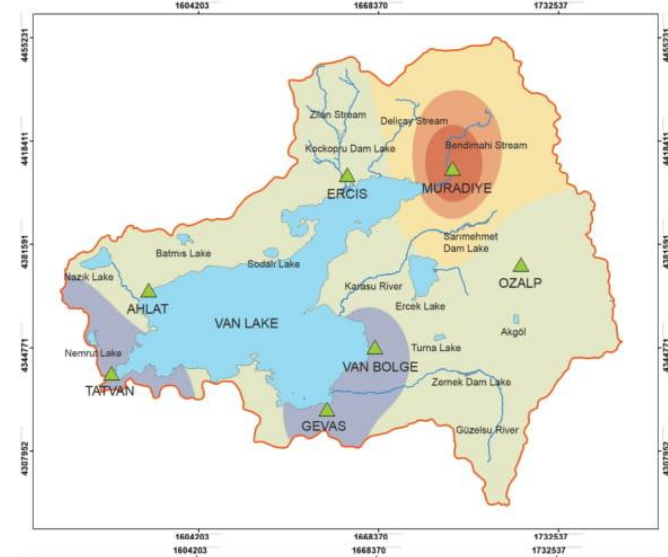

Drought Analysis According to SPI Values

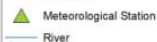

$\square$ Lake Van Basitin

SPI Values. 2016

Extreme Drought (-4-2-2) Severe Prought (-1.99 - - 1.50)

Moderate Drought (-1.4.

Moderate Wet $(1-1.49$

1 severe Wert $(1.50 \cdot 1.99)$

Extremely Wet (2-4)
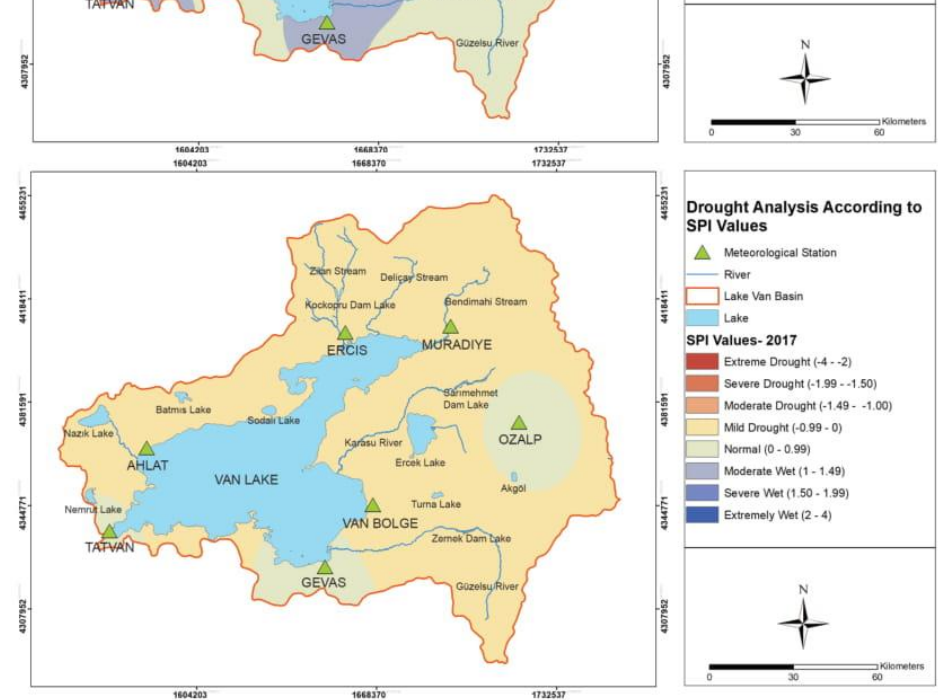

SPI Values

$\triangle$ Metecrological Station

$\square$ Lat

Lake Van Basin

SPI Values- 2017

Extreme Drought (-4.-2)

W Doderate Drought (-1.49 - - -1.00

Mili Drought $-0.99-0$

Nong

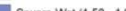

Severe Wet (1.50-1.99)

Extremely Wot (2-4)

Figure 8: Drought Analysis (2014-2017) 


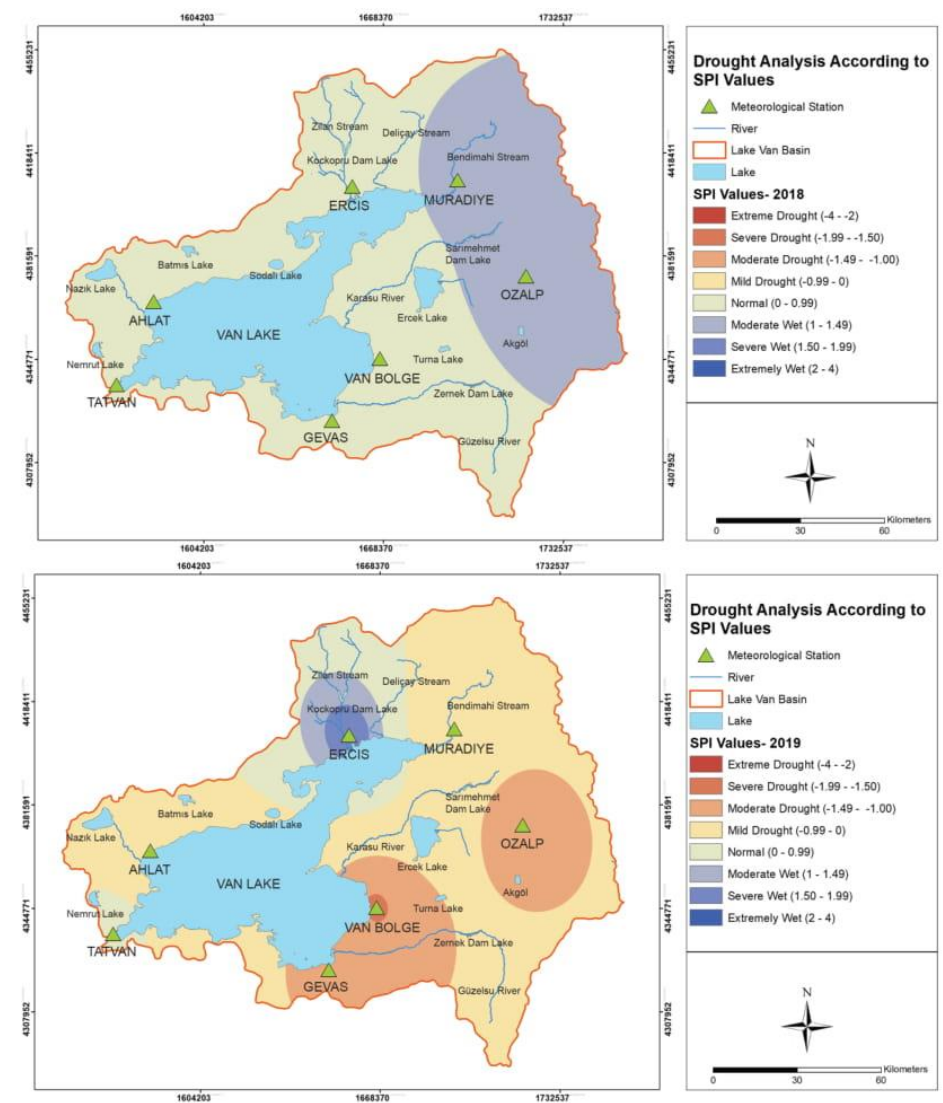

Figure 9: Drought Analysis (2018-2019)

In summary, according to Figure 7 , the basin did not struggle with high severity drought in 2014, 2015 and 2018. In 2010, there was a moderate dry level in the west of the basin, while more than half of the basin was normal and mild drought. The basin received abundant precipitation in 2018. Severe dry drought was observed, which was the highest level for the basin in 2012, 2013, 2016, and 2019. Lake Van Basin did not experience extreme dry level droughts between 2010 and 2019 .

The considerable level of drought was severe dry level experienced in Lake Van Basin. In light of these analyses, it is possible to say that drought may be experienced in the following years. The effects of the drought that may be experienced are not limited to the area where it occurs, so its effects should be reduced. For this, past drought analysis should be considered and monitored constantly. Using these analyses, resilience strategies should be determined and implemented to reduce the drought and its effects in the coming years and to make the basin more resilient.

\section{Results and Discussion}

An online interview was made with a relevant expert (personal communication, on December 12 , 2020), who worked as a project expert in the process of Lake Van Basin Drought Management Plan. In this interview, the planning process, drought effects, causes and feasible resilience strategies for the basin were discussed. The most important output of the meeting was the determination of resilient strategies for the basin.

Lake Van Basin Drought Management Plan identified strategies that were critical for the future of the basin and the cities in the basin. Drought analysis, water potential, hydrological models and future forecasts and change of water potential were made in plan. In addition to these, 
climate projections, drought risk, severity maps and possible results were presented. It was calculated how much water the agriculture, industry, drinking water, ecosystem and tourism sectors used and how much water they would use with projections made for the future. The future water amounts and needs were compared, and finally, precautions and strategies against drought were developed. Making predictions ensure that the basin is resilient to drought and the steps to be taken in this direction are efficient and the effects of drought will decrease in the coming years. The strong effects that the plan provides to the basin are awareness of society, knowledge of water needs and future water needs, making measurements that have not been made before, and starting to implement the necessary strategies to reduce the effects of drought.

One of the main causes of drought in the basin in the coming years is the effects of increasing climate change. When the Lake Van Basin Drought Management Plan RCP4.5 scenario was evaluated for all model results, it was revealed that temperatures would increase by approximately $3^{\circ} \mathrm{C}$ especially after 2060 and these increases would be more in the southern parts of the basin. According to the RCP8.5 scenario, it was determined that the temperature increases would reach $5^{\circ} \mathrm{C}$ at the end of the century.

While the effects of increasing climate change induce the drought, there are also different reasons for drought peculiar to the region. The first of these is the misuse of water. Especially the use of drinking water in the agricultural sector and the irrigation of agricultural lands with improper techniques increases water use. According to the studies in the Drought Management Plan, open irrigation technique was used throughout the basin except for Ahlat and Ovakısla, furthermore, the amount of water used was unknown. Since the underground and spring waters were not measured, the amount of water used and the change of water level over the years was unknown. However, it is possible to say that water decreases as a result of misuse techniques and improper water usage. As is the case with the misuse of water in agriculture, it is necessary to enhance public awareness in all sectors and in terms of drinking water and to change water usage habits because coping with the drought is both an individual and a collective process.

Another reason for excessive water use for Lake Van Basin is that water use is not constantly monitored. According to the interview and plan, the rate of leakage in the basin was $70 \%$ in 2018 , in addition, there was no observation and measurement continuity of groundwater. This situation led to the fact that it was not known how much water was actually used in the basin and how many water resources remained. Unknown uses cause drought with excessive use of water, and also prevents taking the right decisions and precautions against drought for stakeholders.

The basin experienced drought before, and according to the plan, water demand will occur in the southeast of the basin in 2025 at the earliest. Namely, it is certain that the basin will experience drought again in the following years; thus, effective basin management should be provided together with strategies to reduce drought and its effects. For this reason, the main problem of the basin is that the measures are not carried out as soon as possible despite the drought. At the same time, the solutions determined should be specific to the basin. Otherwise, the strategies and measures taken will not help reduce the drought. For this reason, attention was paid to ensure that the strategies determined in this study were appropriate and applicable to the basin. In the strategies determined, not only Lake Van Basin, but also the ecosystem was considered as a whole because while the rivers of the basin generally flow into Lake Van, some of them reach the Persian Gulf and Iran. For example, strategies such as water transportation between basins that are both costly and harmful to the ecosystems of other basins were avoided and the decision was made with global thinking. 
Lake Van Basin is a region where leakage water rates are high hence, leakages and unregistered subscribers should be prevented. The entire infrastructure system should be followed by GIS-based software. In addition to this system, water levels and quality should also be kept under control; meteorological, hydrological data and flow measurement network should be strengthened, and continuity of observations should be ensured. In addition to monitoring and control systems, drought monitoring and early warning systems should also be established. With the Supervisory Control and Data Acquisition system (SCADA), water level, pressure, speed, critical points, leakage, and the water distribution system should be checked and monitored. With this system, leakages are controlled with an effective pressure management, and the water is distributed to the user in a controlled manner (Thornton ve Lambert, 2006). In addition, considering that water distribution consumes energy, it contributes to being resilient by providing energy savings with controlled distributions.

One of the most important issues in the strategies was agriculture, which is the most important sector of the basin and the sector where the most economic production is made. To understand the importance of this basin's drought strategy, one must ask the question, "Is there a product that Turkey depends on the Lake Van Basin?" In order to find an answer to this question, agricultural products grown in the basin and having a large proportion in Turkey were listed. Table 3 shows that the most produced agricultural products in 2019 were clover (local name korunga), dried bean, clover (local name yonca), potato (except yam), green bean, tomato, apricot (local name zerdali) and walnut. 17.94\% of clover (local name korunga), and $5.19 \%$ of clover (local name yonca) produced in Turkey were graown in Lake Van Basin. Also, these products are used in livestock. That is to say in case of extreme or severe drought, the livestock sector will also be affected immediately after the agricultural sector will be affected. The pattern of products grown in the basin may change with the increasing temperature and water use over the years, so strategies to protect these products in the basin should be determined. Growing crops that can grow in the basin with less water needs should be encouraged. These conservation strategies will also affect the livestock sector and the basin economy.

One of the exemplary countries in the strategies that can be taken against drought in agriculture is Israel. The country, where drinking water was used in agriculture in the 1960s and endeavour with chronic water scarcity, later made changes in this situation. Two strategies have been effective in agriculture with the use of waste water in agriculture and the application of subsurface drip irrigation without exception. Open irrigation reached $40 \%$ efficiency, while subsurface drip irrigation reached a $70 \%$ to $80 \%$ with less evaporation (Megersa and Abdulahi, 2015). Using wastewater in agriculture is a common method. Wastewater is purified and used in agriculture. This method provides economic benefit and water savings with both waste water disposal. On the other hand, less water is used with high efficiency and the risk of flood is reduced. Improper irrigation methods and drinking water use in agriculture should be prevented. It is necessary to use pressurized and drip irrigation technique by preventing flooding in the basin and wastewater treatment systems should be developed. 
Table 3. The Most Produced Agricultural Products in The Basin in 2019 (TUIK, 2020, Crop Production Statistics)

\begin{tabular}{lccc}
\hline \hline & $\begin{array}{c}\text { Production in } \\
\text { Turkey(tons) }\end{array}$ & $\begin{array}{c}\text { Production in } \\
\text { Basin (tons) }\end{array}$ & Percent (\%) \\
\hline Clover (Korunga) & $1,781,789$ & 319,742 & 17.94 \\
Dried Bean & 225,000 & 23,773 & 10.57 \\
Clover (Yonca) & $17,949,264$ & 931,350 & 5.19 \\
Potato (Except yam) & $4,979,824$ & 192,560 & 3.87 \\
Green Bean & 596,074 & 6,505 & 1.09 \\
Tomato & $8,836,055$ & 166,767 & 1.89 \\
Apricot (Zerdali) & 17,250 & 299 & 1.73 \\
Walnut & 225,000 & 3,655 & 1.62 \\
\hline \hline
\end{tabular}

Wastewater treatment systems should also be used in the industrial sector. According to the Drought Management Plan, it was predicted that $30 \%$ ( $0.74 \mathrm{hm} 3 /$ year) savings could be achieved from the water consumption of $2.47 \mathrm{hm}^{3} /$ year for 2018 , which is consumed by the industrial facilities in the basin, with water treatment techniques. In this way, a remarkable amount of water is reused and savings are achieved in the basin.

In addition to the given strategies, rainwater harvesting was considered the most suitable solution. Rainwater harvesting is a method that has been used for more than 4000 years, that rainwater is collected and reused by simple methods or advanced engineering methods. Sudden and prolonged precipitations due to low soil permeability in the city cause floods. Rainwater harvesting not only provides drought resistance, but also helps prevent floods; moreover, it is unnecessary to spend energy to lift water from underground (UN-HABITAT, 2005).

It is a strategy that can be used for Lake Van Basin to protect the existing water in years when there is no meteorological drought, since the water source formed by harvesting rainwater is completely dependent on precipitation. It can be used in agriculture, industry and daily use depending on its quality. As stated in the Drought Management Plan, additional precautions that are beneficial to be implemented to reduce the effects of drought in Lake Van Basin: "harvesting rain and snow water in facilities with roofing areas greater than $500 \mathrm{~m}^{2}$ in industrial zones" and "rain water should be used for irrigation with rainwater harvesting techniques". If it is implemented, rain water will be harnested and reused according to its quality and the use of spring water will not be required. Another applicable strategy in Lake Van Basin is the reuse of gray water. Gray water can be defined as limited contaminated domestic wastewater. Gray water is purified after collecting and can be used in many areas such as garden irrigation, car wash, and ornamental pools. It has numerous advantages such as low energy consumption, low waste disposal and reduced fresh water consumption (Oh et al., 2018). In today's conditions, the cost of design may be high, but considering the increased water costs, longterm use and the benefits it provides, it may be financially more affordable (Zadeh et al., 2013).

According to the Lake Van Basin Drought Management Plan, the water level of Nemrut Lake, located in the west of the basin, has dropped over the years. It is estimated that the water levels of other lakes will decrease with the enhancing temperature and usage. Two strategies were considered for this: the first was to prevent evaporation by using chemicals and the second by using anti-evaporation balls. Although it can be physically feasible to the lakes in the basin, it was not found suitable because the operation load is high and the main material 
of the balls is plastic, and it will affect the water and ecological life in the basin (Haghighi et al., 2018). Anti-evaporation balls endanger the life of land creatures because their structure is made of plastic and completely covers the lake surface. It also disrupts the ocean ecosystem with harmful microorganisms formed over time. Therefore, the implementation of this strategy is not appropriate.

\section{Conclusion}

Prolonged drought events adversely affect the ecosystem, human life, ground and surface waters, and all sectors. Turkey experienced severe drought in 2017-2018 period. During these years, drinking and irrigation water decreased, human activities were negatively affected. Although droughts were experienced in Turkey in 1971-1974, 1983-1984, 1989$1990,1996-2001$ and there will be droughts in the coming years, it is seen that there is no resilience to reduce the drought and its effects. For these reasons, the effects of the drought have shown themselves to be severe. If strategies, implementations, basin and water management are not provided effectively, future droughts will be more severe with increasing climate change impacts.

Among the years examined, 2018 was the only year in which normal and moderate wet levels were seen in the entire Lake Van Basin. There were severe droughts in 2012, 2013, 2016 and 2019 , although there was no extreme drought. This indicates that severe drought will occur in the following years. It can affect all areas of life, starting with a meteorological drought. The economic and social sustainability of the basin depends on the agricultural sector. As included in this definition, Lake Van Basin is directly dependent on precipitation with its lifestyle and production systems. For this reason, droughts that will occur in the basin are very important. The drought may create more physical, social, and economic effects than expected.

Based on the importance of the drought for Lake Van Basin, following resilience strategies suitable for the basin were determined:

- Implementation of the Lake Van Basin Drought Management Plan strategies, ensuring effective basin water management.

- Raising public awareness on industrial, agricultural and drinking water use and changing water usage habits in order to fight drought, which is an individual and collective process.

- Monitoring the infrastructure system with GIS-based software and providing controlled water distribution in order to reduce high leakage water amounts and unregistered subscribers.

- In order to keep water levels and quality under control, as well as monitoring and control systems, implementation of Supervisory Control and Data Acquisition system (SCADA). In addition, controlling the water level, pressure, speed, critical points and leaks in the water distribution system with this system.

- Creation of drought monitoring and early warning systems.

- Preventing the misuse of water in the agricultural sector.

- Crop conservation by changing crop patterns with increasing drought and temperature will primarily affect the agriculture and livestock sector.

- Determination of alternative agricultural products for the livestock sector, which is of great importance in the region.

- Treating wastewater and using it in agriculture, thus ensuring wastewater disposal, economic benefits and water savings.

- Implementation of underground drip irrigation without exception.

- Treatment and reuse of industrial wastewater. 
- Providing reuse of water by harvesting rain water to prevent floods.

- Preventing floods and ensuring water reuse with rainwater harvesting.

- Reuse of domestic wastewater, called gray water, thereby providing numerous advantages such as low energy consumption, low waste disposal and reduced freshwater consumption.

If Lake Van Basin experiences droughts as meteorological droughts in the past, it is estimated that it will be more resilient to these droughts thanks to the strategies. If the strategies are applied to other basins in a collective process, the characteristics of the area and precipitation and strategies followed throughout the country should be considered, and a certain resilience to the future droughts is provided. In this way, the possibility of drought in the coming years in Lake Van Basin, which has an important place for Turkey, will be reduced. If there is a drought, it will be overcome with less damage with the measures taken and strategies applied.

\section{References}

Agnew, M., Palutikof, J. (2000). GIS-based construction of baseline climatologies for the Mediterranean using terrain variables. Clim Res 14: 115-127. doi:10.3354/cr014115

Arslan, O. , Bilgil, A. \& Veske, O. (2016). Standart Yağiş Indisi Yöntemi lle Kizilirmak Havzasi'nin Meteorolojik Kuraklik Analizi . Niğde Ömer Halisdemir Üniversitesi Mühendislik Bilimleri Dergisi , 5 (2) , 188-194 . Doi: 10.28948/Ngumuh.295572

Atmaca, D. (2011). Standartlaştırılmış yağış indeksi (SYI) yöntemi ile Konya ili bölgesel kuraklık analizi, Master's thesis, Gaziosmanpaşa Üniversitesi, Fen Bilimleri Enstitüsü, Tokat, Türkiye.

Aydın, O., \& Çiçek, I. (2013). Spatial Distribution of Precipitation In Aegean Region. Turkish J. of Geographical Sciences, 11(2), 101-120.

Bacanlı, Ü. G., \& Kargı, P. G. (2019). Uzun Ve Kısa Süreli Periyotlarda Kuraklık Analizi: Bursa Örneği. Doğal Afetler Ve Çevre Dergisi, 5(1), 166-174. Retrived from: http://dacd.artvin.edu.tr/en/download/article-file/553712. Last Access: 22.10.2021

Bakanoğulları, F. (2020). Kırsal Havzalarda Kuraklığın İki Yöntem (SPEI ve SPI) Kullanılarak Belirlenmesi: Kumdere Havzası Örneği . Türk Tarım ve Doğa Bilimleri Dergisi , 7 (1) , 146-156 . DOI: 10.30910/turkjans.680037

Beden, N. , Demir, V. \& Ülke Keskin, A. (2020). Samsun İlinde SPI ve PNI Kuraklık İndekslerinin Eğilim Analizi . Dokuz Eylül Üniversitesi Mühendislik Fakültesi Fen ve Mühendislik Dergisi , 22 (64) , 107-116 . DOI: 10.21205/deufmd.2020226411

Borges, P,A., Franke, J., Santos Silva, F., Weiss, H., Bernhofer, C., (2014). Differences between two climatological periods (2001-2010 vs. 1971-2000) and trend analysis of temperature and precipitation in Central Brazil. Theor Appl Climatol 116:191-202. doi:10.1007/ s00704-013-0947-4

Çaldağ, B., Şaylan, L., Toros, H., Sirdaş, S., Bakanoğullari, F. (2004). Drought Analysis in Northwest Turkey", Role of Multipurpose Agriculture in Sustaining Global Environment, 169179. Udine, Italy. 
Çelik, M. A. , Kopar, İ. \& Bayram, H. (2018). Doğu Anadolu Bölgesi'nin Mevsimlik Kuraklık Analizi . Atatürk Üniversitesi Sosyal Bilimler Enstitüsü Dergisi , 22 (3) , 1741-1761.

Retrieved from https://dergipark.org.tr/en/pub/ataunisosbil/issue/39594/464898. Last Access: 22.10 .2021

Dikici M., (2019), Asi Havzası'nda (Türkiye) kuraklık analizi, Doğal Afetler ve Çevre Dergisi, $5(1), 22-40$.

Dinç, N., Aydinşakir, K., Işık, M. \& Büyüktaş, D. (2016). Standartlaştırılmış Yağış Indeksi (SPI) Yöntemi lle Antalya Ili Kuraklık Analizi. Derim, 33(2), 279-298. Retrieved from: http://www.derim.com.tr/en/download/article-file/234540. Last Access: 22.10.2021

Doğru, A. Ö., Keskin, M., Özdoğdu, K., İliev, N., Uluğtekin, N. N., Balçık, Bektaş, F., Göksel, Ç., Sözen, S. (2011). Meteorolojik Verilerin Değerlendirilmesi ve Sunulması İçin Enterpolasyon Yöntemlerinin Karşılaştırılması, TMMOB Coğrafi Bilgi Sistemleri Kongresi, Antalya, Türkiye.

Fidan, H.I. (2011). Doğu Akdeniz Bölgesinde standardize yağış indeksi (SYì) ile kuraklık analizi ve markov zinciri yöntemini kullanarak kurak olma olasılıklarının belirlenmesi, Master's thesis, Çukurova Üniversitesi, Fen Bilimleri Enstitüsü, Adana, Türkiye.

Folke, C., Carpenter, S., Elmqvist, T., Gunderson, L., Holling, C. S., \& Walker, B. (2002). Resilience And Sustainable Development: Building Adaptive Capacity In A World Of Transformations. AMBIO: A journal of the human environment, 31(5), 437-440.

Franke, R., \& Nielson, G. (1980). Smooth Interpolation of Large Sets Of Scattered Data. International Journal For Numerical Methods İn Engineering, 15(11), 1691-1704.

Giddings, L., SOTO, M., Rutherford, B. M., \& Maarouf, A. (2005). Standardized Precipitation Index Zones For Mexico. Atmósfera, 18(1), 33-56.

Gümüş, V. , Başak, A. \& Oruç, N. (2016). Standartlaştırılmış Yağış İndeksi (SYi) Yöntemi ile Şanlıurfa İstasyonunun Kuraklık Analizi . Harran Üniversitesi Mühendislik Dergisi , 1 (1) , 36 44 . Retrieved from: https://dergipark.org.tr/en/pub/humder/issue/28975/309942. Last Access: 22.10.2021

Goovaerts, P., (2000). Geostatistical approaches for incorporating elevation into the spatial interpolation of rainfall. J Hydrol 228:113-129. doi: 10.1016/S0022-1694(00)00144-X

Haberlandt, U., (2007). Geostatistical interpolation of hourly precipitation from rain gauges and radar for a large-scale extreme rainfall event. J Hydrol 332:144-157.

doi:10.1016/j.jhydrol.2006.06.028

Haghighi, E., Madani, K., \& Hoekstra, A. Y. (2018). The water footprint of water conservation using shade balls in California. Nature Sustainability, 1(7), 358-360. doi: 10.1038/s41893-0180092-2

Hınıs, M.A., (2008) Standart Yağış İndeksi ile Konya'nın Geçmişten Günümüze Kuraklık Değerlendirmesi, 5. Dünya Su Forumu Türkiye Bölgesel Su Toplantıları-Konya Kapalı Havzası Yeraltısuyu ve Kuraklık Konferansı, 238-245, Konya, Türkiye. 
İrcan, M. R. \& Duman, N. (2021). Standartlaştırımış Yağış İndisi (SYi) Yöntemi ile Şanlıurfa İli Kuraklık Analizi* . Coğrafya Dergisi , (42) , 1-18. Retrieved from: https://dergipark.org.tr/tr/pub/iucografya/issue/63677/963639. Last Access: 22.10.2021

Jha, A. K., Miner, T. W., \& Stanton-Geddes, Z. (Eds.). (2013). Building urban resilience: principles, tools, and practice. World Bank Publications.

Kadıoğlu, M. (2008). Kuraklık Kıranı Risk Yönetimi. In: Kadıoğlu, M. ve Özdamar, E., (Ed.), Afet Zararlarını Azaltmanın Temel İlkeleri, JICA Türkiye Ofisi Yayınları No: 2 277-300. Ankara.

Keskin, M. E., Terzi, Ö., Taylan, E. D., \& Yılmaz, A. G. (2007). Isparta Bölgesi Meteorolojik Kuraklık Analizi, I. Türkiye İklim Değişikliği Kongresi (TiKDEK), 11-13.

Keskiner, A. D. , Çetin, M. , Uçan, M. \& Şimşek, M. (2016). Coğrafi Bilgi Sistemleri Ortamında Standardize Yağış İndeksi Yöntemiyle Olasılıklı Meteorolojik Kuraklık Analizi: Seyhan Havzası Örneği . Çukurova Tarım ve Gıda Bilimleri Dergisi , 31 (2) , 79-90 . Retrieved from https://dergipark.org.tr/en/pub/cutarim/issue/30643/332139. Last Access: 22.10.2021

Kumanlioglu, A. \& Fıstıkoğlu, O. (2019). Yukarı Gediz Havzası Yağışlarının Meteorolojik Kuraklık Analizleri . Dokuz Eylül Üniversitesi Mühendislik Fakültesi Fen ve Mühendislik Dergisi , 21 (62) , 509-523 . DOI: 10.21205/deufmd.2019216216

McKee, T. B., Doesken, N. J., \& Kleist, J. (1993). The Relationship Of Drought Frequency And Duration To Time Scales. In Proceedings of the 8th Conference on Applied Climatology,17(22),179-183.

Megersa, G., \& Abdulahi, J. (2015). Irrigation System in Israel: A review. International Journal of water resources and environmental engineering, 7(3), 29-37.

Mishra, A. K., \& Singh, V. P. (2010). A review of drought concepts. Journal of hydrology, 391(12), 202-216. doi: 10.1016/j.jhydrol.2010.07.012

Oğuz, K. , Pekin, M. A. \& Çamalan, G. (2021). Muğla İlinde 1960-2018 Dönemi Kuraklık Analizi . Doğal Afetler ve Çevre Dergisi , 7 (1) , 89-100 . DOI: 10.21324/dacd.774955

Oğuztürk, G. \& Yıldız, O. (2014). Drought Analysis for Different Time Periods in the City of Kırıkkale . International Journal of Engineering Research and Development , 6 (2) , 19-25. DOI: 10.29137/umagd.346084

Oğuztürk, G. (2010). Kızılırmak Havzası'nda SYì ile kuraklık analizi ve YSA yöntemi ile kuraklık tahmini, Master's thesis, Kırıkkale Üniversitesi, Fen Bilimleri Enstitüsü, Kırıkkale, Türkiye.

Oh, K. S., Leong, J. Y. C., Poh, P. E., Chong, M. N., \& Von Lau, E. (2018). A review of greywater recycling related issues: Challenges and future prospects in Malaysia. Journal of Cleaner Production, 171, 17-29. doi: 10.1016/j.jclepro.2017.09.267

Özfidaner, M. \& Topaloğlu, F. (2020). Standart Yağış İndeksi Yöntemi ile Güneydoğu Anadolu Bölgesinde Kuraklık Analizi . Toprak Su Dergisi , 9 (2) , 130-136 . DOI: 10.21657/topraksu.767002 
Pamuk, G., Özgürel, M., \& Topçuoğlu, K. (2004). Standart yağış indeksi (SYİ) ile Ege Bölgesinde kuraklık analizi. Ege Üniversitesi Ziraat Fakültesi Dergisi, 41(1):99- 106.

Republic Of Turkey Ministry Of Agriculture And Forestry, General Directorate Of Water Management, Flood And Drought Management Department. (2018) Lake Van Basin Drought Management Plan.

Portalés, C., Boronat, N., Pardo-Pascual, J.E., Balaguer-Beser, A. (2010). Seasonal precipitation interpolation at the Valencia region with multivariate methods using geographic and topographic information. Int J Climatol 30(10):1547-1563. doi:10.1002/joc.1988

Sarış, F. \& Gedik, F. (2021). Konya Kapalı Havzası'nda Meteorolojik Kuraklık Analizi . Coğrafya Dergisi , (42) , 295-308 . Retrieved from:

https://dergipark.org.tr/en/pub/iucografya/issue/63677/885519. Last Access: 22.10.2021

Şener E., Şener Ş., (2019), Meteorolojik kuraklığın coğrafi bilgi sistemleri tabanlı zamansal ve konumsal analizi: Çorak Gölü Havzası (Burdur-Türkiye) örneği, Mühendislik Bilimleri ve Tasarım Dergisi, 7(3), 596-607.

Şener, E. \& Şener, Ş. (2021). SPI ve CZI Kuraklık İndislerinin CBS Tabanlı Zamansal ve Konumsal Karşılaştırması: Burdur Gölü Havzası Örneği . Doğal Afetler ve Çevre Dergisi , 7 (1) , 41-58 . DOI: 10.21324/dacd.800036

Sırdaş S., Şen Z., (2003), GAP Bölgesinde Kurak Dönem Özelliklerinin Araştırılması, III. Atmosfer Bilimleri Sempozyumu, 19-21 Mart, İstanbul, Türkiye, ss.305-317.

Taylan, D. \& Bahşi, A. M. (2021). Gaziantep İli Meteorolojik Kuraklık Analizi ve KAS İlişkisi . Süleyman Demirel Üniversitesi Fen Bilimleri Enstitüsü Dergisi , 25 (2) , 371-382. DOI:10.19113/sdufenbed.868780

Thornton, J., \& Lambert, A. (2006). Managing pressures to reduce new breaks. Water, 21(8), 24-26.

Topçuoğlu, K., Mengü, G.P., Anaç, S. (2008) “Ege Bölgesi Meteorolojik Kuraklık Analizi”, 5. Dünya Su Forumu Türkiye Bölgesel Su Toplantıları-Konya Kapalı Havzası Yeraltısuyu ve Kuraklık Konferansı, 175- 184, Konya, Türkiye.

Tsakiris, G., \& Vangelis, H. (2004). Towards A Drought Watch System Based On Spatial SPI. Water Resources Management, 18(1), 1-12.

Türkeş, M. (2012). A Detailed Analysis Of The Drought, Desertificatıon And The United Natıons Conventıon To Combat Desertıfıcatıon. Aegean Geographical Journal, 20 (1), 7-55.

Türkeş, M. (2017). Drought Vulnerability and Risk Analysis of Turkey with Respect to Climatic Variability and Socio-Ecological Indicators. Aegean Geographical Journal, 26 (2), 47-70.

Turkish State Meteorological Service (2020). Drought and Classification. Retrieved from: https://mgm.gov.tr/veridegerlendirme/kuraklik-analizi.aspx?d=yontemsinif\#sfB. Last Access: 25.01 .2020

Turkish Statistical Institute (TUIK). (2020) Address Based Population Registration System. Retrieved from: https://biruni.tuik.gov.tr/medas/?kn=95\&locale=en. Last Access: 25.01.2020 
Turkish Statistical Institute (TUIK). (2020) Crop Production Statistics. Retrieved from: https://biruni.tuik.gov.tr/medas/?kn=92\&locale=en. Last Access: 25.01 .2020

Uçar, Y., Topçu, E., \& Demirel, E. (2019). Standartlaştırılmış Yağış İndeksi Yöntemi ile Isparta İli Kuraklık Analizi. Türk Bilim ve Mühendislik Dergisi, 1(1), 5-16. Retrived from: https://dergipark.org.tr/en/download/article-file/912197. Last Access: 22.10.2021

UN-HABITAT (2005). Rainwater Harvesting and Utilisation. BlueDrops Series (Book3), United Nations Habitat Programme, Nairobi, Kenya. Retrieved from: https://unhabitat.org/blue-dropseries-on-rainwater-harvesting-and-utilisation-book-3project-managers-and-implemetationagency. Last Access: 25.01.2020

Walker, B., Holling, C. S., Carpenter, S. R., \& Kinzig, A. (2004). Resilience, Adaptability And Transformability İn Social-Ecological Systems. Ecology And Society, 9(2). Retrieved from: http://www.ecologyandsociety.org/vol9/iss2/art5/. Last Access: 25.01.2020

Wilhite, D.A. (2000). Drought As A Natural Hazard: Concepts And Definitions. In: Wilhite, D.A. (Ed.), Drought: A Global Assessment, Vol. 1. Routledge, New York, 1-18.

Wilhite, D.A., Glantz, M,H. (1987). Understanding the drought phenomena: the role of definitions. In: Donald, A., Wilhite, Easterling Willam, E., Deobarah, A., (Eds.), Planning of Drought: Towards a Reduction of Societal Vulnerability, Westview Press, Wood, Boulder, CO, $11-27$.

World Meteorological Organization (WMO). (1986). Report on Drought and Countries Affected by Drought During 1974-1985, WMO, Geneva,118.

Yeğnidemir, M.K. (2005). İç Anadolu Bölgesinin Standartlaştırılmış Yağış İndeksi Metodu ile Kuraklık Analizi, Master's thesis, Kırıkkale Üniversitesi, Fen Bilimleri Enstitüsü, Kırıkkale, Türkiye.

Yetmen, H. (2015). Van Gölü Havzası'nın Kuraklık Analizi . 21. Yüzyılda Eğitim Ve Toplum Eğitim Bilimleri Ve Sosyal Araştırmalar Dergisi , 2 (5) , 184-198 . Retrieved from: https://dergipark.org.tr/en/pub/egitimvetoplum/issue/5128/69926. Last Access: 22.10.2021

Yüceerim, G. , Yılmaz, G. , Etöz, M. \& Acar, C. O. (2019). Kocadere Havzasında Standartlaştırılmış Yağış İndeksi İle Farklı Zaman Ölçeğinde Kuraklık Analizi . Toprak Su Dergisi, Özel Sayı , 70-76 . DOI: 10.21657/topraksu.655270

Yürekli, K. \& Anlı, S., (2008). Standartlaştırılmış Yağış İndeksi ile Karaman İli Kuraklığının Analizi, 5. Dünya Su Forumu Türkiye Bölgesel Su Toplantıları-Konya Kapalı Havzası Yeraltısuyu ve Kuraklık Konferansı, 246-251.

Zadeh, S. M., Hunt, D. V., Lombardi, D. R., \& Rogers, C. D. (2013). Shared urban greywater recycling systems: water resource savings and economic investment. Sustainability, 5(7), 2887-2912. 